\title{
Feeding of Phytobiotics and Exogenous Protease in Broilers: Comparative Effect on Nutrient Digestibility, Bone Strength and Gut Morphology
}

\author{
Abdul Hafeez ${ }^{1}$, Shahid Iqbal ${ }^{1}$, Arbab Sikandar ${ }^{2}$ D, Salahud Din ${ }^{3}$, Imad Khan ${ }^{4}$, Saima Ashraf ${ }^{5}$, \\ Rifat Ullah Khan ${ }^{6, *(D)}$, Vincenzo Tufarelli ${ }^{7, *(D)}$ and Vito Laudadio ${ }^{7}$
}

Citation: Hafeez, A.; Iqbal, S.; Sikandar, A.; Din, S.; Khan, I.; Ashraf, S.; Khan, R.U.; Tufarelli, V.; Laudadio,

V. Feeding of Phytobiotics and Exogenous Protease in Broilers: Comparative Effect on Nutrien Digestibility, Bone Strength and Gut Morphology. Agriculture 2021, 11 228. https://doi.org/10.3390/ agriculture 11030228

Academic Editors: Maria Grazia Cappai and Secundino López

Received: 25 January 2021

Accepted: 7 March 2021

Published: 9 March 2021

Publisher's Note: MDPI stays neutral with regard to jurisdictional claims in published maps and institutional affiliations.

Copyright: (c) 2021 by the authors. Licensee MDPI, Basel, Switzerland This article is an open access article distributed under the terms and conditions of the Creative Commons Attribution (CC BY) license (https:// creativecommons.org/licenses/by/ $4.0 /)$
1 Department of Poultry Science, Faculty of Animal Husbandry \& Veterinary Sciences, The University of Agriculture, Peshawar 25120, Pakistan; hafeez@aup.edu.pk (A.H.); shahidiqbal801@gmail.com (S.I.)

2 Department of Basic Sciences, College of Veterinary and Animal Sciences (Sub Campus, Jhang), University of Veterinary and Animal Sciences, Lahore 54000, Pakistan; arbab.sikandar@uvas.edu.pk

3 Department of Anatomy and Histology, Faculty of Veterinary and Animal Sciences, Islamia University Bahawalpur, Bahawalpur 63100, Pakistan; salahudin@yahoo.com

4 College of Veterinary Sciences and Animal Husbandry, Abdul Wali Khan University, Mardan 23200, Pakistan; imadkhan@awkum.edu.pk

5 Department of Anatomy and Histology, University of Veterinary and Animal Sciences, Lahore 54000, Pakistan; saima.ashraf@uvas.edu.pk

6 College of Veterinary Sciences, Faculty of Animal Husbandry \& Veterinary Sciences, The University of Agriculture, Peshawar 25000, Pakistan

7 Section of Veterinary Science and Animal Production, Department of DETO, University of Bari 'Aldo Moro', Valenzano, 70010 Bari, Italy; vito.laudadio@uniba.it

* Correspondence: rukhan@aup.edu.pk (R.U.K.); vincenzo.tufarelli@uniba.it (V.T.)

Abstract: In this feeding trial, a total of 500 Cobb-500 broiler (day-old) chickens were randomly assigned to a control dietary treatment (basal diet only) or supplemented with crushed seeds of coriander (Coriandrum sativum L.), black cumin (Bunium persicum (Boiss.) B. Fedtsch) and ajwain (Carum copticum L.) (at $10 \mathrm{mg} / \mathrm{kg}$ each) and exogenous protease (30,000 IU/ kg), respectively, in order to assess the effect of the diets on nutrient digestibility, bone strength and gut morphology. The results indicated that the digestibility coefficients of crude protein, crude fat, nitrogen-free extract, calcium and phosphorous were significantly $(p<0.05)$ higher in protease-treated birds compared to the control. The tibia bone weight was improved ( $p=0.03$ ) in Carum copticum, Coriandrum sativum and protease-supplemented birds. Bone length increased $(p<0.05)$ in protease and Carum copticum fed broilers, while the robusticity index decreased $(p<0.05)$ in all treatments. Villus length and width decreased $(p<0.05)$ in Carum copticum and Bunium persicum fed broilers. From findings, it was demonstrated that exogenous protease shows comparatively better results in improving bone quality, ileal digestibility and villus morphology in broilers.

Keywords: broiler; feed additives; phytobiotics; protease enzymes

\section{Introduction}

In modern broiler production, the use of antibiotics as growth promoters is inevitable due to their positive impacts on broiler health and production [1-3] However, due to certain well-known adverse effects such as antimicrobial resistance and meat residues, the use of antimicrobial drugs has been subjected to severe criticism, and their uncontrolled use has been curtailed in many developed countries of the world [4-6]. There is a continuous search for nonantibiotic compounds such as herbs, organic acids, probiotics, postbiotics and others to sustain growth in broilers with no side effects on the end of consumers [7-11]. Studies have shown that different feed additives from herbs and medicinal plants have shown increased importance due to their antimicrobial, antioxidant, antifungal and digestive enzymes stimulating activities in broiler chickens [12]. Enzyme supplementation in poultry 
diets has been justified for nutritional, economical and environmental reasons. Enzyme access to the substrate determines the quantity of energy derived by the broiler from the plant materials. The exogenous supplementation of enzymes has several important functions such as increasing the digestion of nutrients, reducing the excretion of nitrogen to the environment and improving the performance of the broiler [11,13]. However, the results published to date are not consistent.

Coriandrum sativum (coriander) is a well-known spice among herbs. In traditional medicine, it has been used as a remedy for several diseases such as diarrhea, dyspepsia, stomach ulcer and anti-inflammatory conditions. Research reports have also documented antifungal, antioxidant, hypolipidemic and hypocholesterolemic effects [14]. Many important alkaloids such as linalool, pinede, terpinene, geranyl acetate, camphor and geraniol have been isolated from the essential oil of coriander [15]. Bunium persicum (black cumin) is another herbal plant well known for its antimicrobial activities [16]. It has been used as a carminative for disorders of the gastrointestinal tract such as diarrhea and dyspepsia since ancient times [17]. In addition, it has shown antimicrobial and antioxidant activities [18]. Carum copticum (ajwain) is known for correcting ailments of the digestive tract [19]. Others have reported its antibacterial and antioxidant effects, which may result in better feed utilization and enhanced growth in broilers [20]. In addition, Carum copticum has been known for some other properties such as antioxidant, antimicrobial, antispasmotic and antifungal. Protease, a proteolytic enzyme, is now extensively used as a supplement in broiler rations due to its well-known effects on improved nutrient digestibility. Research studies have documented higher digestibility, lower abdominal fat and enhanced bone strength in broilers in response to the exogenous supplementation of protease enzymes [2,11].

To our knowledge, few studies have compared the effect of supplementation of herbal plants and protease enzymes; therefore, the purpose of the current study was to evaluate the comparative effects of protease enzymes and different herbal plants on gut morphology, ileal digestibility and bone strength in broilers.

\section{Materials and Methods}

\subsection{Ethical Statement}

This study has been approved by the Ethical Committee on Animal Rights and Welfare, Faculty of Animal Husbandry and Veterinary Sciences, The University of Agriculture, Peshawar.

\subsection{Broiler Management}

A total of 500 Cobb-500 broiler chickens (day-old) were randomly distributed into five dietary treatments (100 birds/treatment) and five replicates (20 birds/replicate) in a completely randomized design as follows: one group was fed a basal diet consisting of a corn-soybean meal as the control, while the other groups were supplemented with a fine powder of the seeds of Carum copticum, Coriandrum sativum and Bunium persicum at the rate of $10 \mathrm{mg} / \mathrm{kg}$ per diet each. The fifth group was supplemented with protease enzyme at the rate of 30,000 IU $/ \mathrm{kg}$ diet (Ronozyme ${ }^{\circledR}$, Basel, Switzerland). The basal diets consisting of starter and finisher phases were provided to birds according to the NRC [21], as shown in Table 1. The feed supplements were mixed in a small quantity of a meshed basal diet of their respective groups, and it was ensured that the supplements were completely consumed by the birds. The supplements were added to the diets starting from the second week of the experiment until the fifth week of age. Broilers were reared on the floor at a density rate of 9.5 birds $/ \mathrm{m}^{2}$. During brooding, the room temperature was set at $35 \pm 2{ }^{\circ} \mathrm{C}$ and then gradually brought to a normal temperature of $25 \pm 2{ }^{\circ} \mathrm{C}$. The proximate analysis and chemical composition of the medicinal plants are given in Table 2. 
Table 1. Composition and chemical composition of the basal diets.

\begin{tabular}{ccc}
\hline Ingredients, $\%$ & Starter Phase & Finisher Phase \\
\hline Corn & 55.50 & 56.01 \\
Soybean meal $(44 \% \mathrm{CP})$ & 27.40 & 26.52 \\
Canola meal & 6.51 & 6.00 \\
Sunflower meal & 3.21 & 3.51 \\
Vegetable oil & 1.82 & 1.93 \\
Molasses & 1.00 & 1.00 \\
Dicalcium phosphate & 1.91 & 1.92 \\
Limestone & 1.00 & 1.00 \\
NaCl & 1.00 & 1.00 \\
NAHCO 3 & 0.21 & 0.21 \\
Vitamin-mineral premix 1 & 0.31 & 0.31 \\
Chemical composition & & \\
ME, kcal $/$ kg & 3000 & 3150 \\
Crude protein, \% & 23.50 & 21.30 \\
Methionine, $\%$ & 0.55 & 0.44 \\
Lysine, $\%$ & 1.42 & 1.23 \\
Sulfur amino acids, \% & 0.96 & 0.80 \\
Threonine, \% & 0.95 & 0.85 \\
Calcium, \% & 1.05 & 0.90 \\
Phosphorus, \% & 0.50 & 0.45 \\
\hline
\end{tabular}

${ }^{1}$ Vitamin-mineral premix contains in the following per kg: vitamin A, 2,400,000 IU; vitamin D, 1,000,000 IU, vitamin E, 16,000 IU; vitamin K, $800 \mathrm{mg}$; vitamin B1, $600 \mathrm{mg}$; vitamin $\mathrm{B}_{2}, 1600 \mathrm{mg}$; vitamin $\mathrm{B}_{6}, 1000 \mathrm{mg}$; vitamin $\mathrm{B}_{12}$, $6 \mathrm{mg}$; niacin, $8000 \mathrm{mg}$; folic acid, $400 \mathrm{mg}$; pantothenic acid, $3000 \mathrm{mg}$; biotin $40 \mathrm{mg}$; antioxidant, $3000 \mathrm{mg}$; cobalt, $80 \mathrm{mg}$; copper, $2000 \mathrm{mg}$; iodine, 400; iron, $1200 \mathrm{mg}$; manganese, 18,000 mg; selenium, $60 \mathrm{mg}$, and zinc, $14,000 \mathrm{mg}$.

Table 2. Proximate analysis and chemical composition of seeds of Coriandrum sativum, Bunium persicum and Carum copticum (per $100 \mathrm{~g}$ sample $w / w$ ).

\begin{tabular}{cccc}
\hline Ingredients & Coriandrum sativum & Bunium persicum & Carum copticum \\
\hline Crude fat, g & 9.31 & 10.32 & 18.3 \\
Crude protein, g & 13.56 & 12.54 & 15.3 \\
Crude fiber, g & 35.78 & 22.33 & 11.8 \\
Vitamins & & & \\
Vitamin C, mg & 28 & 14 & 17 \\
Vitamin E, mg & 2.4 & 1.8 & 2.2 \\
Vitamin A, $\mu \mathrm{g}$ & 335 & 231 & 189 \\
Vitamin B complex, mg & 2.1 & 1.5 & 1.8 \\
Vitamin K, $\mu \mathrm{g}$ & 313 & 213 & 145 \\
Minerals & & & \\
Calcium, mg & 63 & 23 & 1.43 \\
Iron, mg & 1.33 & 2.3 & 14.2 \\
Magnesium, mg & 0.45 & 0.9 & 1.1 \\
Phosphorous, mg & 45 & 12 & 0.32 \\
Potassium, mg & 531 & 123 & 302 \\
Sodium, mg & 45 & 32 & 12 \\
Zinc, mg & 0.49 & 1.2 & 0.98 \\
\hline
\end{tabular}

\subsection{Apparent Ileal Digestibility}

For the determination of apparent ileal digestibility, chromium oxide $(5 \mathrm{~g} / \mathrm{kg})$ was mixed as the inert compound three days before the end of the experiment. Fecal samples were collected and stored at a refrigerated temperature until analysis. The apparent ileal digestibility of the broilers was determined by randomly selecting three birds from each replicate and subjected them to slaughtering with a sharp knife. After removing the skin, the abdomen was opened, and ileal digesta were collected. Digesta were dried, sampled then analyzed for apparent nutrient digestibility as described by the AOAC [22] using the following formula: 
Apparent Ileal Digestibility $=100-\frac{\text { conc. of marker in feed }}{\text { conc. of marker in digesta }} \times \frac{\text { conc. of nutrient in digesta }}{\text { conc. of nutrient in feed }} \times 100[0,1]$

Samples were also analyzed for calcium and phosphorus using atomic absorption and a spectrophotometer, respectively. The samples were prepared as described by Khan et al. [23]. Briefly, about $1 \mathrm{~g}$ of ileal digesta was taken in a conical flask and mixed with $5 \mathrm{~mL}$ of perchloric acid. The mixture was heated until the fumes were flown away and then allowed to cool. The mixture was again mixed with $5 \mathrm{~mL}$ of nitric oxide and the mixture was heated. Distilled water was added to the mixture to make a final volume of $10 \mathrm{~mL}$.

\subsection{Ileal Morphology}

Three birds per replicate were randomly selected and slaughtered and defeathered. The abdomen was opened, and the ileum was identified. A piece about $1 \mathrm{~cm}^{2}$ was separated from the ileum and then preserved in $10 \%$ formalin followed by paraffin embedding. Slides were prepared following staining with hematoxylin and eosin. Slide samples were analyzed at $10 \times$ under a microscope (Olympus, NV, Aartselaar, Belgium) for villus dimensions as described by Abudabos et al. [5]. The distance between the tip and base was considered the height of the papilla, and the width was taken as the average width of the tip, middle portion and base of the papilla. Papilla surface area was calculated using the formula:

$$
[2 \times(\mathrm{W} / 2) \times \mathrm{L}] \text {, where } \mathrm{W}=\text { papilla width and } \mathrm{L}=\text { papilla length. }
$$

\subsection{Bone Quality}

Right tibia bones were collected from the slaughtered birds and boiled at $100{ }^{\circ} \mathrm{C}$ for $8 \mathrm{~min}$ followed by air drying. The bones were weighed using a digital balance. Other parameters were determined using the following formula:

$$
\text { Weight } / \text { length }=\text { weight }(\mathrm{mg}) / \text { length }(\mathrm{mm})
$$

Robusticity index = bone length $(\mathrm{mm}) /$ cube root of bone weight $(\mathrm{mg})$

Tibiotarsal index $=($ diaphysis diameter-medullary canal diameter $/$ diaphysis diameter $) \times 100$

\subsection{Statistical Analysis}

The investigated different parameters were analyzed through ANOVA using the GLM procedure (SPSS 16.0 software, Inc., Chicago, IL, USA). Treatment means were ranked with the help of Tukey's test as a post-hoc test at $p \leq 0.05$.

\section{Results}

The effect of Carum copticum, Coriandrum sativum, Bunium persicum and the protease enzyme on apparent ileal nutrient digestibility is given in Table 3 . No significant difference was found in the digestibility of dry matter and ash between the control and other treatment groups. The results indicated that the digestibility of crude protein, crude fat, nitrogen-free extract and calcium were significantly $(p<0.01)$ higher in protease-treated birds compared to the control.

The results of Carum copticum, Coriandrum sativum, Bunium persicum and protease on bone quality are given in Table 4 . Bone weight was improved $(p<0.05)$ in Coriandrum sativum and protease-supplemented birds. The bone length was significantly $(p=0.05)$ increased in protease and Carum copticum supplemented birds, while the robusticity index decreased $(p<0.05)$ in all the supplemented birds. The tibiotarsal index did not change $(p>0.05)$ among dietary treatments. 
Table 3. Effect of adding herbal plant feed additives and protease on apparent ileal nutrient digestibility (\%) in broilers.

\begin{tabular}{cccccccc}
\hline Item & Control & $\begin{array}{c}\text { Carum } \\
\text { copticum }\end{array}$ & $\begin{array}{c}\text { Coriandrum } \\
\text { sativum }\end{array}$ & $\begin{array}{c}\text { Bunium } \\
\text { persicum }\end{array}$ & $\begin{array}{c}\text { Protease } \\
\text { Enzyme }\end{array}$ & Pooled SEM & $p$ Value \\
\hline Dry Matter & 65.5 & 65.7 & 65.6 & 66.0 & 65.2 & 3.54 \\
Ash & $43.8^{\mathrm{n}}$ & 43.2 & 43.6 & $43.6^{\mathrm{b}}$ & 43.6 & 0.68 \\
Crude Protein & $69.8^{\mathrm{b}}$ & $70.7^{\mathrm{ab}}$ & $72.2^{\mathrm{ab}}$ & $67.6^{\mathrm{b}}$ & $74.2^{\mathrm{a}}$ & 1.56 & $<0.01$ \\
Crude Fat & $82.1^{\mathrm{b}}$ & $82.8^{\mathrm{b}}$ & $85.0^{\mathrm{a}}$ & $80.7^{\mathrm{b}}$ & $85.9^{\mathrm{a}}$ & 4.21 & $<0.01$ \\
Nitrogen-Free Extract & $80.9^{\mathrm{b}}$ & $81.3^{\mathrm{b}}$ & $83.6^{\mathrm{a}}$ & $79.9^{\mathrm{b}}$ & $84.0^{\mathrm{a}}$ & 6.54 & $<0.01$ \\
Calcium & $31.5^{\mathrm{b}}$ & $31.6^{\mathrm{b}}$ & $32.4^{\mathrm{ab}}$ & $30.3^{\mathrm{b}}$ & $33.3^{\mathrm{a}}$ & 1.22 & $<0.01$ \\
Phosphorus & $31.9^{\mathrm{b}}$ & $31.4^{\mathrm{b}}$ & $31.9^{\mathrm{b}}$ & $29.3^{\mathrm{b}}$ & $34.2^{\mathrm{a}}$ & 3.22 & $<0.01$ \\
\hline
\end{tabular}

a,b: Means having different superscripts in the same row show a significant difference $(p<0.05)$. SEM: standard error of means.

Table 4. Effect of addition of herbal plant feed additives and protease on bone characteristics in broilers.

\begin{tabular}{cccccccc}
\hline Item & Control & $\begin{array}{c}\text { Carum } \\
\text { copticum }\end{array}$ & $\begin{array}{c}\text { Coriandrum } \\
\text { sativum }\end{array}$ & $\begin{array}{c}\text { Bunium } \\
\text { persicum }\end{array}$ & $\begin{array}{c}\text { Protease } \\
\text { Enzyme }\end{array}$ & Pooled SEM & $p$ Value \\
\hline Bone weight $(\mathrm{g})$ & $6.36^{\mathrm{b}}$ & $6.88^{\mathrm{ab}}$ & $8.16^{\mathrm{a}}$ & $6.84^{\mathrm{b}}$ & $7.42^{\mathrm{a}}$ & 0.322 & 0.03 \\
Bone length $(\mathrm{mm})$ & $88.9^{\mathrm{b}}$ & $89.5^{\mathrm{ab}}$ & $88.4^{\mathrm{b}}$ & $88.1^{\mathrm{b}}$ & $91.2^{\mathrm{a}}$ & 0.801 & 0.05 \\
W/L index & $248^{\mathrm{b}}$ & 253 & $252^{\mathrm{b}}$ & $251^{\mathrm{b}}$ & 250 & 1.666 & 0.07 \\
Robusticity index & $5.02^{\mathrm{a}}$ & $4.74^{\mathrm{b}}$ & $4.36^{\mathrm{b}}$ & $4.81^{\mathrm{b}}$ & $4.61^{\mathrm{b}}$ & 0.093 & 0.04 \\
Tibio-tarsal index & 33.7 & $33.1^{\mathrm{b}}$ & 34.0 & 34.7 & 32.5 & 0.782 & 0.06 \\
\hline
\end{tabular}

a,b: Means having different superscripts in the same row show a significant difference $(p<0.05)$. SEM: standard error of means.

The effect of Carum copticum, Coriandrum sativum, Bunium persicum and protease enzyme on the villus histology is given in Table 5. Villus length and width decreased $(p<0.05)$ in Carum copticum and Bunium persicum fed broilers, whereas the other investigated parameters such as crypt depth, lamina propria and the villus length to crypt depth ratio were not changed $(p>0.05)$.

Table 5. Effect of adding herbal plant feed additives and protease in feed on ileum morphology in broilers.

\begin{tabular}{cccccccc}
\hline Item & Control & $\begin{array}{c}\text { Carum } \\
\text { copticum }\end{array}$ & $\begin{array}{c}\text { Coriandrum } \\
\text { sativum }\end{array}$ & $\begin{array}{c}\text { Bunium } \\
\text { persicum }\end{array}$ & $\begin{array}{c}\text { Protease } \\
\text { Enzyme }\end{array}$ & $\begin{array}{c}\text { Pooled } \\
\text { SEM }\end{array}$ & $\begin{array}{c}p \text { Value } \\
\text { SEM }\end{array}$ \\
\hline Villus length $(\mu \mathrm{m})$ & $448.23^{\mathrm{a}}$ & $413.78^{\mathrm{b}}$ & $436.89^{\mathrm{ab}}$ & $429.66^{\mathrm{b}}$ & $436.11^{\mathrm{ab}}$ & 0.061 \\
Villus width $(\mu \mathrm{m})$ & $130.44^{\mathrm{ab}}$ & $100.9^{\mathrm{b}}$ & $140.12^{\mathrm{a}}$ & $0110.54^{\mathrm{b}}$ & $130.65^{\mathrm{a}}$ & 0.012 & 0.02 \\
Crypt depth $(\mu \mathrm{m})$ & 250.12 & 240.34 & 240.33 & 250.12 & 230.17 & 0.012 & 0.07 \\
Lamina propria $(\mu \mathrm{m})$ & 0.06 & 0.06 & 0.06 & 0.06 & 0.06 & 0.001 & 0.06 \\
VL/CD & 1.79 & 1.72 & 1.81 & 1.71 & 1.89 & 0.345 \\
Villus surface area $\left(\mathrm{mm}^{2}\right)$ & 0.61 & 0.57 & 0.60 & 0.56 & 0.59 & 0.044 \\
\hline
\end{tabular}

$\mathrm{a}, \mathrm{b}$ : Means having different superscripts in the same row show a significant difference $(p<0.05)$. SEM: standard error of means; VL/CD, villus length to crypt depth ratio.

\section{Discussion and Conclusions}

Available reports have provided conflicting results in relation to the effects on growth, histological features, blood metabolites and digestibility in response to the dietary supplementation of Coriandrum sativum, Carum copticum, Bunium persicum and exogenous protease enzymes in broiler chickens [24-32]. The differences in the results on these parameters have been mainly linked to the antinutritional factors, feed composition and environmental stressors, broiler strain, dose and duration of supplementations [33]. The obtained findings on the apparent nutrient digestibility in broilers in response to the different feed additives were not consistent. In this regard, crude protein digestibility was significantly improved in protease enzyme supplementation compared to the control and B. persicum. Moreover, crude fat and nitrogen-free extract coefficients were improved in Coriandrum sativum and protease-enzyme-supplemented birds. Similarly, calcium was 
significantly improved in protease and Coriandrum sativum supplemented birds; however, phosphorous was significantly improved in the protease-supplemented group. Carum copticum has been reported for many medicinal properties due to the presence of several bioactive compounds such as limonene, myrcene, b-pinene, $\mathrm{p}$-cymene and $\gamma$-terpinene. Seeds of Carum copticum have a significant role in digestive disorders and liver diseases. Similarly, Bunium persicum has a number of important compounds such as cuminaldehyde, b-pinene, 4-dien-7-algamma-terpinene and p-mentha-1. A mixture of Carum copticum and Bunium persicum in different concentrations $(10 \mathrm{mg} / \mathrm{kg})$ has been previously reported to improve the apparent nutrient digestibility in broilers [32]. Improved crude protein and fat digestibility have also been reported recently by Shuaib et al. [8] in response to $0.5 \%$ Bunium persicum in broilers, although other parameters for nutrients digestibility were not affected. In the current study, enhanced results were found for digestibility indices in response to protease supplementation compared to the other treatments. Improved digestibility of nutrients has been reported in broilers in response to protease supplementation [11]. The plausible reasons for the positive effects of protease have been attributed to reduced antinutritional factors, protein digestibility and the modification of intestinal microflora. Enhanced digestibility in herbal-plant-fed broilers could be due to the stimulation of digestive enzyme secretion in response to the supplementations. In addition, improved bone measurements and histological features may also be due to enhanced digestibility indices in broilers fed with protease enzyme.

In the current study, bone weight was increased significantly in Coriandrum sativum and protease-enzyme-supplemented birds compared to the control. Few studies have evaluated bone strength in response to enzyme and medicinal plant supplementation. Recently, Hafeez et al. [32] did not find any significant effect on bone weight in broilers supplemented with a mixture of Bunium persicum, Trigonella foenum-graecum and Carum copticum. Leg problems are economically important in broiler production due to their fast growth since the bones in these animals are not as strong as in local breeds. In the current study, the significant increase in bone weight in protease-enzyme-supplemented birds may correlate with the weight gain in these birds or can be attributed to better bone mineralization. Similarly, bone length increased significantly in protease and Carum copticum supplemented birds compared to the control. In a similar study, Hafeez et al. [2] did not find significant differences in bone length in broilers supplemented with a Carum copticum, Trigonella foenum-graecum and Bunium persicum mixture at the rate of 1.5, 3 and $4.5 \mathrm{~g} / \mathrm{kg}$. It seems that dose levels are highly important in determining the effects of the medicinal plants in broilers. The robusticity index was decreased significantly in the treatment group. A lower robusticity index indicates stronger bone. Unlike our results, Hafeez et al. [32] did not find any significant difference in bone quality and strength index in broilers fed with Carum copticum, Bunium persicum and fenugreek.

In the current study, villus length and villus width decreased significantly in Carum copticum and Bunium persicum supplemented birds. Histological features of the intestine were comparatively improved in Coriandrum sativum and protease-enzyme-supplemented birds. Previously, Alam et al. [34] reported improved villus dimensions in Japanese quails supplemented with phytase enzyme. Similar findings were reported in an experiment on broilers fed with C. copticum, T. foenum-graecum and B. persicum [2,35]. In the published literature, there are scarce reports on the effects of musculoskeletal and histological features in response to herbal and protease feed additives in broilers. Therefore, we cannot ascertain the exact mechanism through which the feed additives modulate these parameters in broilers. From the published data on weight gain [32], it seems that the improved bone strength and villus dimensions are correlated to the enhanced weight gain in these birds in their respective groups.

Based on the findings, it was concluded that compared to phytobiotics, the effect of protease enzyme has comparatively better effects on nutrient digestibility and bone quality in broilers. However, histological features are partially improved in the proteasesupplemented group compared to the phytobiotics. 
Author Contributions: Conceptualization, A.H., S.I., R.U.K. and V.T.; methodology, S.I., A.S., R.U.K., V.T. and V.L.; validation, R.U.K., V.T. and V.L.; formal analysis, A.H., S.I., A.S., S.D., I.K., S.A. and R.U.K.; investigation, A.H., S.I., S.D., I.K., S.A. and R.U.K.; data curation, S.I., A.S., R.U.K., V.T. and V.L.; writing - original draft preparation, A.H., S.I., R.U.K. and V.T.; writing-review and editing, R.U.K., V.T. and V.L. All authors have read and agreed to the published version of the manuscript.

Funding: The current study was supported by Higher Education Commission of Pakistan (HEC) under Startup Research Grant Program (SRGP) through project No. 21-1561/SRGP/R\&D/HEC/2017.

Institutional Review Board Statement: This study was approved by the Ethical Committee on Animal Welfare and Rights approved by the Faculty of Animal Husbandry and Veterinary Sciences, The University of Agriculture, Peshawar, Pakistan (Approval Number 127/2020).

Informed Consent Statement: Not applicable.

Data Availability Statement: Data presented in this study are available on fair request from the respective author.

Acknowledgments: The authors would like to specially thank the lab technicians involved.

Conflicts of Interest: The authors declare no conflict of interest.

\section{References}

1. Khan, R.; Naz, S.; Nikousefat, Z.; Tufarelli, V.; Laudadio, V. Thymus vulgaris: Alternative to antibiotics in poultry feed. World Poult. Sci. J. 2012, 68, 401-408. [CrossRef]

2. Hafeez, A.; Shah, S.A.A.; Khan, R.U.; Ullah, Q.; Naz, S. Effect of diet supplemented with phytogenics and protease enzyme on performance, serum biochemistry and muscle histomorphology in broilers. J. Appl. Anim. Res. 2020, 48, 326-330. [CrossRef]

3. Laudadio, V.; Nasiri-Dehbaneh, M.; Bilal, R.M.; Qotbi, A.; Javandel, F.; Ebrahimi, A.; Seidavi, A.; Slozhenkina, M.; Gorlov, I.; Dunne, P.G.; et al. Effects of different levels of dietary black cumin (Nigella sativa L.) and fenugreek (Trigonella foenum-graecum L.) and their combination on productive traits, selected blood constituents, microbiota and immunity of broilers. Anim. Biotechnol. 2020, 1-14. [CrossRef] [PubMed]

4. Khan, R.; Naz, S.; Nikousefat, Z.; Tufarelli, V.; Javdani, M.; Qureshi, M.S.; Laudadio, V. Potential applications of ginger (Zingiber officinale) in poultry diets. World Poult. Sci. J. 2012, 68, 245-252. [CrossRef]

5. Abudabos, A.M.; Alyemni, A.H.; Dafalla, Y.M.; Khan, R.U. The effect of phytogenics on growth traits, blood biochemical and intestinal histology in broiler chickens exposed to Clostridium perfringens challenge. J. Appl. Anim. Res. 2018, 46, 691-695. [CrossRef]

6. Safiullah; Chand, N.; Khan, R.U.; Naz, S.; Ahmad, M.; Gul, S. Effect of ginger (Zingiber officinale Roscoe) and organic selenium on growth dynamics, blood melanodialdehyde and paraoxonase in broilers exposed to heat stress. J. Appl. Anim. Res. 2019, 47, 212-216. [CrossRef]

7. Abudabos, A.M.; Alyemni, A.H.; Dafalla, Y.M.; Khan, R.U. The effect of phytogenic feed additives to substitute in-feed antibiotics on growth traits and blood biochemical parameters in broiler chicks challenged with Salmonella typhimurium. Environ. Sci. Pollut. Res. 2016, 23, 24151-24157. [CrossRef]

8. Shuaib, M.; Ullah, N.; Hafeez, A.; Alhidary, I.A.; Abdelrahman, M.M.; Khan, R.U. Effect of dietary supplementation of wild Cumin (Bunium persicum) seeds on performance, nutrient digestibility and circulating metabolites in broiler chicks during the finisher phase. Anim. Biotechnol. 2020, 1-5. [CrossRef]

9. Haq, I.U.; Hafeez, A.; Khan, R.U. Protective effect of Nigella sativa and Saccharomyces cerevisiae on zootechnical characteristics, fecal Escherichia coli and hematopoietic potential in broiler infected with experimental Colibacillosis. Livest. Sci. 2020, 239, 104119. [CrossRef]

10. Humam, A.M.; Loh, T.C.; Foo, H.L.; Izuddin, W.I.; Awad, E.A.; Idrus, Z.; Samsudin, A.A.; Mustapha, N.M. Dietary Supplementation of Postbiotics Mitigates Adverse Impacts of Heat Stress on Antioxidant Enzyme Activity, Total Antioxidant, Lipid Peroxidation, Physiological Stress Indicators, Lipid Profile and Meat Quality in Broilers. Animal 2020, 10, 982. [CrossRef]

11. Jabbar, A.; Tahir, M.; Khan, R.U.; Ahmad, N. Interactive effect of exogenous protease enzyme and dietary crude protein levels on growth and digestibility indices in broiler chickens during the starter phase. Trop. Anim. Health Prod. 2021, 53, 23. [CrossRef] [PubMed]

12. Khan, S.H.; Ansari, J.; Haq, A.U.; Abbas, G. Black cumin seeds as phytogenic product in broiler diets and its effects on per-formance, blood constituents, immunity and caecal microbial population. Ital. J. Anim. Sci. 2012, 11, e77. [CrossRef]

13. Watts, E.S.; Rose, S.P.; MacKenzie, A.M.; Pirgozliev, V.R. The effects of supercritical carbon dioxide extraction and cold-pressed hexane extraction on the chemical composition and feeding value of rapeseed meal for broiler chickens. Arch. Anim. Nutr. 2019, 74, 57-71. [CrossRef]

14. Hosseinzadeh, H.; Qotbi, A.A.A.; Seidavi, A.; Norris, D.; Brown, D. Effects of Different Levels of Coriander (Coriandrum sativum) Seed Powder and Extract on Serum Biochemical Parameters, Microbiota, and Immunity in Broiler Chicks. Sci. World J. 2014, 2014, 1-11. [CrossRef] 
15. Burdock, G.A.; Carabin, I.G. Safety assessment of coriander (Coriandrum sativum L.) essential oil as a food ingredient. Food Chem. Toxicol. 2009, 47, 22-34. [CrossRef]

16. Sekine, T.; Sugano, M.; Majid, A.; Fujii, Y. Antifungal Effects of Volatile Compounds from Black Zira (Bunium persicum) and Other Spices and Herbs. J. Chem. Ecol. 2007, 33, 2123-2132. [CrossRef]

17. Tehseen, M.; Tahir, M.; Khan, R.U.; Jabbar, A.; Ahmad, B.; Ahsan, T.; Khan, M.S.; Khan, S.; Abudabos, A.M. Additive effect of Nigella sativa and Zingiber officinale herbal mixture on performance and cholesterol profile in broiler. Philip. Agric. Sci. 2016, 99, 408-413.

18. Sacchetti, G.; Maietti, S.; Muzzoli, M.; Scaglianti, M.; Manfredini, S.; Radice, M.; Bruni, R. Comparative evaluation of 11 es-sential oils of different origin as functional antioxidants, antiradicals and antimicrobials in foods. Food Chem. 2005, 91, 621-632. [CrossRef]

19. Valiollahi, M.R.; Gholami, M.; Namjoo, A.R.; Rahimian, Y.; Rafiee, A. Effect of using sumac (Rhus coriaria L.) and ajwain (Trachyspermum copticum) powders on performance and intestinal microbial population in broiler chicks. Res. Opin. Anim. Vet. Sci. 2014, 4, 545-549.

20. Falaki, M.; Shams Shargh, M.; Dastar, B.; Hashemi, S.R.; Sadeghi, M. Growth performance, carcass characteristics and intestinal microflora of broiler chickens fed diets containing carum copticum. J. Poult. Sci. 2016, 4, 37-46.

21. NRC, National Research Council. Nutritional Requirements of Poultry, 9th ed; The National Academies Press: Washington, DC, USA, 1994.

22. AOAC. Official Method of Analysis, 17th ed.; Association of Official Analytical Chemists: Gaithersbug, MD, USA, 2000.

23. Khan, R.U.; Javed, I.; Muhammad, F. Effects of vitamins, probiotics and protein level on semen traits and some seminal plasma macro and micro minerals of male broiler breeders after zinc-induced molting. Biol. Trace Elem. Res. 2012, 148, 44-52. [CrossRef]

24. Ghazi, S.R.; Rooke, J.A.; Galbraith, H.; Bedford, M.R. The potential for the improvement of the nutritive value of soya-bean meal by different proteases in broiler chicks and broiler cockerels. Br. Poult. Sci. 2002, 43, 70-77. [CrossRef]

25. Gracia, M.I.; Araníbar, M.J.; Lazaro, R.; Medel, P.; Mateos, G.G. Alpha-amylase supplementation of broiler diets based on corn. Poult. Sci. 2003, 82, 436-442. [CrossRef]

26. Onderci, M.; Sahin, N.; Sahin, K.; Cikim, G.; Aydín, A.; Ozercan, I.; Aydín, S. Efficacy of supplementation of $\alpha$-amylase-producing bacterial culture on the performance, nutrient use, and gut morphology of broiler chickens fed a corn-based diet. Poult. Sci. 2006, 85, 505-510. [CrossRef]

27. Guler, T.; Ertas, O.N. The effect of dietary black cumin seeds on the performance of broilers. Asian-Australas. J. Anim. Sci. 2006, 19, 425-430. [CrossRef]

28. Jang, I.; Ko, Y.; Kang, S.; Lee, C. Effect of a commercial essential oil on growth performance, digestive enzyme activity and intestinal microflora population in broiler chickens. Anim. Feed. Sci. Technol. 2007, 134, 304-315. [CrossRef]

29. Khaligh, F.; Sadeghi, G.; Karimi, A.; Vaziry, A. Evaluation of different medicinal plants blends in diets for broiler chickens. J. Med. Plants Res. 2011, 5, 1971-1977.

30. Dosković, V.; Bogosavljević-Bosković, S.; Pavlovski, Z.; Milošević, B.; Škrbić, Z.; Rakonjac, S.; Petričević, V. Enzymes in broiler diets with special reference to protease. World Poult. Sci. J. 2013, 69, 343-360. [CrossRef]

31. Shroha, A.; Bidhan, D.S.; Yadav, D.C.; Rohila, H. Ajwain as non-antibiotic growth promoter in Broiler industry: A review. J. Pharma. Innov. 2019, 8, 518-524.

32. Hafeez, A.; Sohail, M.; Ahmad, A.; Shah, M.; Din, S.; Khan, I.; Shuiab, M.; Nasrullah; Shahzada, W.; Iqbal, M.; et al. Selected herbal plants showing enhanced growth performance, ileal digestibility, bone strength and blood metabolites in broilers. J. Appl. Anim. Res. 2020, 48, 448-453. [CrossRef]

33. Tufarelli, V.; Laudadio, V.; Casalino, E. An extra-virgin olive oil rich in polyphenolic compounds has antioxidant effects in meat-type broiler chickens. Environ. Sci. Pollut. Res. 2016, 23, 6197-6204. [CrossRef] [PubMed]

34. Alam, S.; Masood, S.; Zaneb, H.; Rabbani, I.; Khan, R.U.; Shah, M.; Ashraf, S.; Alhidary, I.A. Effect of Bacillus cereus and Phytase on the Expression of Musculoskeletal Strength and Gut Health in Japanese Quail (Coturnix japonica). J. Poult. Sci. 2020, 57, 200-204. [CrossRef] [PubMed]

35. Khan, R.U.; Naz, S.; Javdani, M.; Nikousefat, Z.; Selvaggi, M.; Tufarelli, V.; Laudadio, V. The use of turmeric (Curcuma longa) in poultry diets. World Poult. Sci. J. 2012, 68, 97-103. [CrossRef] 